\title{
PROSPECTS AND CHALLENGES FOR DEVELOPMENT OF SMALL BUSINESS FORMS IN AGRICULTURE OF UKRAINE
}

\author{
LESIA V. ZABURANNA \\ TETIANA V. LUTSKA \\ VADYM A. TKACHUK
}

\begin{abstract}
The article summarizes the practice of creation and functioning of small business forms in agriculture of Ukraine, assesses their role and capabilities at the present stage and in the future, identifies priority, desirable directions for further development of society and mechanisms for their provision. The necessity of implementing a consistent policy of entrepreneurial activity expansion in the rural area is substantiated, in the first place by family farming, which is capable to ensure the maximum employment rate of rural population. Due to the above-mentioned processes, agroholdings have narrowed down the ability of the rural population to conduct agricultural entrepreneurial activity.

It has also been proved that in order to increase the efficiency of agricultural production, the profitability of rural households from the agricultural products production and sale, employment of rural population and the development of the agrarian market's infrastructure, it is necessary to intensify the creation of agricultural servicing cooperatives, especially in sectors where the production of small business forms prevails. It was found that it is extremely important to introduce a permanent state of financial and other support for the development of agricultural servicing cooperatives and small forms of farming in the rural area, focusing on supporting the latter through cooperatives in which they participate.
\end{abstract}

Keywords: agroholdings, households, rural areas employment, agricultural cooperatives, organic agriculture.

JEL codes: C10, C53, D13, Q15, Q18.

Prof. Lesia V. Zaburanna, National University of Life and Environmental Sciences of Ukraine, Kyiv (zaburannal@gmail.com); ORCID iD: 0000-0002-3310-125X.

Dr Tetiana V. Lutska, National University of Food Technologies, Kyiv, Ukraine (tetiana.vale@gmail.com); ORCID iD: 0000-0001-7425-2743.

Prof. Vadym A. Tkachuk, National University of Life and Environmental Sciences of Ukraine, Kyiv (vadtkachuk@hotmail.com); ORCID iD: 0000-0002-9684-8625. 


\section{Introduction}

Ukraine has the second largest acreage of farmland in Europe with a total of 41.5 million hectares of agricultural land (about $70 \%$ of the total area of the country), of which arable land accounts for over 32 million hectares, which is why Ukraine is known as "the breadbasket of Europe". Ukraine benefits from a favourable climate and good quality soil, therefore, Ukraine is one of Europe's leading grain producers: it is the continent's largest producer and exporter of corn, the second largest producer of sunflower seeds and sunflower oil.

Agriculture is an important sector of the economy for many countries, including Ukraine. The main task of agriculture is to maintain food security of the country. Full and effective fulfilment of this task is possible only in case of balanced development of all components of the agrarian sphere under parity conditions of the activities of its participants. However, the transformational processes that take place in the economy of Ukraine and in agriculture, in particular, lead to changes in the social division of labour and activities of different forms of ownership in the countryside. Unfortunately, today it is impossible to talk about full-value development of the agrarian market in Ukraine. This is first and foremost manifested in the prosperity of some subjects of the market (medium and large enterprises), and being in a difficult condition for others - small enterprises. However, special attention should be paid to the research of small forms in agrarian sphere, which can be considered the mainstay of food security of the country, in providing jobs for common rural people.

During the period of land transformation in Ukraine the process of abolition of the state monopoly on land was ongoing. In particular, if at the beginning of the 1990 all the land of Ukraine was in the public domain, at the same period of 2016 the share of private ownership was 52\% (State Statistics Service of Ukraine, 2017). Area of agricultural land of corporate sector decreased, while the area of land of farms and households increased.

After gaining independence, Ukraine entered a long-term agricultural crisis. The employees of the former collective farms (about 7 million people or more than $40 \%$ of Ukraine's rural population) - most of whom subsequently found employment in the new, non-state businesses - were given a land share, or the so-called pai, on the land previously managed by the collective farms, an average of 4 hectares (On Urgent Measures to Accelerate Land Reform in the Field of Agricultural Production, 1994). Many residents, especially the elderly and the inexperienced, without sufficient financial resources or farming technology, unable to run a farm or uninterested in doing so, were forced to lease their pais to agricultural entrepreneurs or to the owners of private farms.

But the employment situation and employment opportunities in rural areas today are disastrous for rural population (Fig. 1), and most often it is impossible to find a job in the community or nearby. Also, it should be noted that agricultural production in 2016 was the main economic activity of the informal sector in rural areas. Analysis of the structure of employment in rural areas shows that approximately 
$20 \%$ are working on commercial farms, whereas about $80 \%$ are self-employed farming households. Data shows that in the last years, the level of self-employed population stabilized at around 2.3 million people.

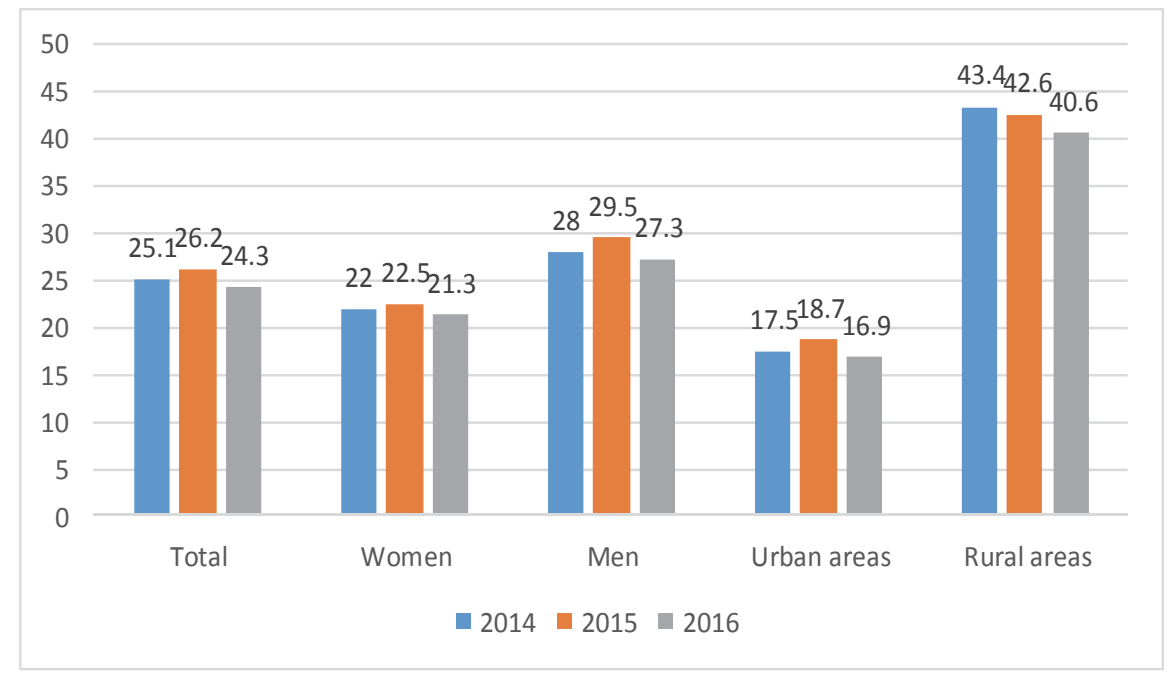

Fig. 1. The 2014-2016 dynamics of informal employment, as \% of the total employed population by respective groups.

Source: based on the data provided by the State Service of Ukraine.

In Ukraine, the most common entities of entrepreneurship in rural areas are agroholdings, farms and household plots.

\section{Objectives and methods}

The objective of this research is to examine a new direction of development of small agriculture enterprises, their main challenges and to outline ways to solve the existing problems. The purpose of the study is to analyse the structure of economic entities in the agrocomplex of Ukraine, identify the positive and negative sides of the identified structure and, based on the results of the study, develop measures and directions to stimulate the development of self-employment among the rural population.

The study uses general scientific and special methods. A methodological base of the study, as to determine rational and effective forms of economy, are general scientific methods. The paper uses the techniques of abstract logical method, namely: analysis, analogy and comparison. In order to assess the effectiveness of economy forms and agricultural competitiveness of Ukraine there were used the methods of tabular data display and statistical indicators analysis. For the paper, there were used analysis of literature on the subject and documents (statistic data) of Ukraine and the European Union, as well as comparative studies. 


\section{Research results and discussion}

Ukraine has thirty million hectares of high-yielding black soil. This incredible national wealth is also the reason for the significant interest from private agribusiness companies and international investors. During the last 15 years agricultural enterprises in Ukraine are being actively restructured and integrated forming large agroholdings.

An agroholding is a type of a consolidated set of parent and controlled subsidiary agricultural companies operating at least 10 thousand hectares. Reaching dozens and even hundreds of thousands hectares of land in size, agroholdings are often part of larger vertically and horizontally integrated business groups.

As of the end of 2017, top 70 agricultural companies in Ukraine operate approximately 6 million ha or roughly $20 \%$ of arable land, of those, the largest company operates more than 600 thousand ha, the smallest one - around 30 thousand ha (National Investment Council of Ukraine, 2018). In Ukraine, the number of agricultural holdings and their land bank continues to grow (Fig. 2). In 2017, there were 93 agricultural enterprises, processing more than 10 thousand hectares. The total land bank in processing by agroholdings for 5 years increased from 5.6 million hectares to 5.95 million hectares in 2017. If we talk in general about the financial indicators of holdings, then over the past year, companies have managed to succeed significantly. Such results were achieved thanks to a trustful relationship with international investors and good macroeconomic situation. Leaders on the land bank remain "Kernel" - 600 thousand hectares, UkrLandFarming - 570 thousand hectares, "Agroprosperis" - 410 thousand hectares.

The main negative consequences of activities of agroholdings in the social context for rural areas of Ukraine are:

- Low employment of the rural population (due to the use of high-tech equipment and technologies, a reduction in the need for living labour force is achieved);

- Absence of tax payments in local budgets (mostly, agricultural holdings as legal entities are registered in large cities, so tax deductions fill the budget of cities, while the agrarian land belonging to the district, villages, rural areas is used. 


\begin{tabular}{|c|c|c|c|}
\hline Company & Specialty & $\begin{array}{l}\text { Revenue, } \\
\text { USD }\end{array}$ & $E B I T D A$ \\
\hline UkrLandFarming & $\begin{array}{l}\text { Crops production } \\
\text { Milk and milk products } \\
\text { Meat production and processing } \\
\text { Eggs and egg products, } \\
\text { Sugar }\end{array}$ & $\begin{array}{l}\text { Publicly not } \\
\text { disclosed }\end{array}$ & $\begin{array}{l}\text { Publicly not } \\
\text { disclosed }\end{array}$ \\
\hline & $\begin{array}{l}\text { Largest producer and exporter of } \\
\text { sunflower oil in the world } \\
\text { Grain storage and trading } \\
\text { Export sea port infrastructure }\end{array}$ & $\begin{array}{l}\text { FY2017: } \\
\text { USD 2,169 m (+9\% } \\
\text { y-o-y) }\end{array}$ & $\begin{array}{l}\text { FY2017: USD } 319 \\
\text { m (8\% y-o-y) }\end{array}$ \\
\hline & $\begin{array}{l}\text { Crops production } \\
\text { (grains and oilseeds) }\end{array}$ & $\begin{array}{l}\text { Publicly not } \\
\text { disclosed }\end{array}$ & $\begin{array}{l}\text { Publicly not } \\
\text { disclosed }\end{array}$ \\
\hline & $\begin{array}{l}\text { Poultry production } \\
\text { and processing } \\
\text { Grain and fodder production } \\
\text { Meat processing }\end{array}$ & $\begin{array}{l}\text { 2017: USD } 1228 \mathrm{~m} \\
(+13 \% \text { y-o-y) } \\
\text { 2016: USD 1,135 m } \\
(+7 \% \text { y-o-y) }\end{array}$ & $\begin{array}{l}\text { 2017: USD } 459 \mathrm{~m} \\
(+11 \%), \\
\text { marg }-36 \% \\
2016: \text { USD } 415 \mathrm{~m} \\
(-5 \%), \operatorname{marg}-37 \%\end{array}$ \\
\hline$\frac{\text { ARTA. NVIV }}{\text { industrial holding }}$ & $\begin{array}{l}\text { Sugar production } \\
\text { Crops production } \\
\text { (grains, oilseeds) } \\
\text { Soybean processing } \\
\text { Milk and milk products } \\
\text { Biogas }\end{array}$ & $\begin{array}{l}\text { 2017: EUR } 459 \mathrm{~m} \\
(+24 \% \text { y-o-y) } \\
\text { 2016: EUR } 369 \mathrm{~m} \\
(+17 \% \text { y-o-y) }\end{array}$ & $\begin{array}{l}\text { 2017: EUR } 120 \mathrm{~m} \\
(-21 \% \mathrm{y}-\mathrm{o}-\mathrm{y}), \\
\text { margin }-32 \% \\
2016: \text { EUR } 152 \mathrm{~m} \\
(+16 \% \mathrm{y}-\mathrm{o}-\mathrm{y}), \\
\text { margin }-41 \% \\
\end{array}$ \\
\hline \multirow{3}{*}{ 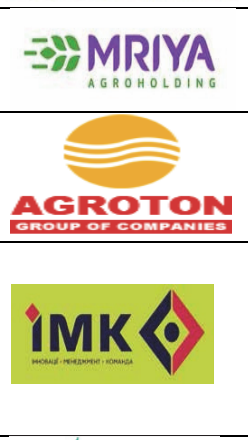 } & $\begin{array}{l}\text { Crop production } \\
\text { (grains, oilseeds, sugar beet, } \\
\text { potatoes) }\end{array}$ & $\begin{array}{l}\text { FY2017: } \\
\text { USD } 90 \mathrm{~m} \\
(+33 \% \text { y-o-y) }\end{array}$ & $\begin{array}{l}\text { FY2017: USD } 8 \mathrm{~m} \\
(+40 \% \text { y-o-y), } \\
\text { margin }-9 \%\end{array}$ \\
\hline & $\begin{array}{l}\text { Crop production } \\
\text { (wheat, sunflower) } \\
\text { Poultry production } \\
\text { Milk and milk products }\end{array}$ & $\begin{array}{l}\text { HY2017: USD } 16.5 \\
\text { m (-5\% y-o-y) } \\
\text { 2016: USD } 44.2 \mathrm{~m} \\
(+5 \% \text { y-o-y) }\end{array}$ & $\begin{array}{l}\text { HY2017: n/a 2016: } \\
\text { USD } 22 \mathrm{~m} \\
(-4 \% \text { y-o-y), } \\
\text { margin }-50 \%\end{array}$ \\
\hline & $\begin{array}{l}\text { Crop production and storage } \\
\text { (grains, oilseeds, soybean, } \\
\text { potatoes) } \\
\text { Milk and milk products }\end{array}$ & $\begin{array}{l}\text { 2017: USD } 127 \mathrm{~m} \\
(+2 \% \text { y-o-y) } \\
2016: \text { USD } 125 \mathrm{~m} \\
(-11 \% \text { y-o-y) }\end{array}$ & $\begin{array}{l}\text { 2017: USD } 39 \mathrm{~m} \\
(-24 \% \mathrm{y}-\mathrm{o}-\mathrm{y}), \\
\text { margin }-\mathrm{x} \% 2016 \text { : } \\
\text { USD } 59 \mathrm{~m} \\
(-10 \% \mathrm{y}-\mathrm{o}-\mathrm{y}), \\
\text { margin }-43 \%\end{array}$ \\
\hline AGRO & $\begin{array}{l}\text { Crop production and processing } \\
\text { (grains, oilseeds, sugar beet) } \\
\text { Sugar production } \\
\text { Milk and milk products }\end{array}$ & $\begin{array}{l}\text { Publicly not } \\
\text { disclosed }\end{array}$ & $\begin{array}{l}\text { Publicly not } \\
\text { disclosed }\end{array}$ \\
\hline & $\begin{array}{l}\text { Crop production and processing } \\
\text { (grains, oilseeds) }\end{array}$ & $\begin{array}{l}\text { HY2017: EUR } 11 \\
\mathrm{~m} \\
(+199 \% \text { y-o-y }) \\
2016: \text { EUR } 60 \mathrm{~m} \\
(+2 \% \text { y-o-y) }\end{array}$ & $\begin{array}{l}\text { HY2017: n/a } \\
2016: \text { EUR } 19 \\
\text { m }(-3 \% \text { y-o-y), } \\
\text { margin }-32 \%\end{array}$ \\
\hline
\end{tabular}

Fig. 2. Key facts about the top 10 agricultural companies in Ukraine.

Source: National Investment Council of Ukraine (2018).

The positive side of the agroholdings' activity is the use of high-tech technologies, however, agricultural holdings specialize mainly in the less labour-intensive branches of farming. There are examples of agroholdings, in which the land occupancy rate is 4.2 times lower than the average in Ukraine. This means that in rural areas where agricultural holdings are functioning, unemployment is much higher. 
To solve all these problems, it is necessary to improve the legal framework that regulates the activity of these structures, in particular concerning:

- Ensuring the transparency of the formation and activities, including the entity structure, the share in the capital, the size and location of the land used, disclosure of the financial reporting;

- Introduction of compulsory participation of agroholding structures in the formation of local budgets, in particular through their registration at the location of the land plot;

- Strengthening their social responsibility and defining mechanisms for participation in environmental protection;

- Introduction of restrictions on the size of the concentration of the land bank within a single territorial community.

The area of land leased by an agroholding group in the territory of a community (administrative district) should not exceed 35\% of the total agricultural land area of this territory, which will enable to provide living space for the development of small and medium forms of business.

The farm is the second and also a special type of entrepreneurial activity of the Ukraine's citizens, which consists in the production, processing and marketing of agricultural products for the purpose of profit.

Small farm enterprises are an integral part of the domestic agro-industrial complex of Ukraine and occupy an important place in ensuring food security (Table 1). According to the State Statistics Service of Ukraine, we have about 32.1 thousand of farm enterprises, $97.5 \%$ of which are small farms. In the structure of domestic farming they cultivate $55.5 \%$ of arable land and produce $52.2 \%$ of gross agricultural output. The overwhelming share of the revenue of small farms (93\%) comes from the selling of crop production indicating the high level of specialization in the field. The most profitable types of products in crop production on small farms are fruit, berries and sunflower seeds, as well as milk in livestock production.

In contrast to agroholdings, small-scale farming has a huge socio-ecological resilience potential and it is a safety net for millions of people. Moreover, household farming is actually resource-efficient, highly productive, and entails social, economic, and ecological benefits for the population as a whole. 
Table 1

The share of farms in the structure of gross output of agricultural enterprises in Ukraine

\begin{tabular}{|c|c|c|c|c|c|}
\hline \multirow{2}{*}{ Indicators } & \multicolumn{5}{|c|}{ Years } \\
\hline & 2000 & 2005 & 2010 & 2015 & 2016 \\
\hline Number of farms, units & 38428.0 & 42447.0 & 41726.0 & 32303.0 & 33682.0 \\
\hline $\begin{array}{l}\text { Share of farms in the total number } \\
\text { of agricultural enterprises, } \%\end{array}$ & - & 73.3 & 73.9 & 71.2 & 70.6 \\
\hline $\begin{array}{l}\text { Gross agricultural products total, } \\
\text { UAH million }\end{array}$ & 3125.2 & 8177.5 & 11965.8 & 18909.3 & 22101.4 \\
\hline $\begin{array}{l}\text { Gross agricultural crop production, } \\
\text { UAH million }\end{array}$ & 2903.3 & 7719.2 & 10840.9 & 17565.4 & 20705.3 \\
\hline $\begin{array}{l}\text { Gross agricultural production } \\
\text { of livestock, UAH million }\end{array}$ & 221.9 & 458.3 & 1124.9 & 1343.9 & 1396.1 \\
\hline \multicolumn{6}{|c|}{ The share of farms in gross agricultural products, $\%$} \\
\hline Gross agricultural products of farms & 5.4 & 11.2 & 12.7 & 14.3 & 15.2 \\
\hline including gross crop production & 92.9 & 94.4 & 90.6 & 93.4 & 93.7 \\
\hline including gross livestock production & 7.1 & 5.6 & 9.4 & 7.1 & 6.3 \\
\hline
\end{tabular}

Source: data of the State Statistics Service of Ukraine, authors' calculations.

Household plot is a legally defined farm type (On the private rural households, 2003) in all former socialist countries in the CIS and CEE. This is a small plot of land attached to a rural residence. The household plot is primarily cultivated for subsistence and its traditional purpose since the Soviet times has been to provide the family with food.

Surplus products from the household plot are sold to neighbours, relatives, and often also in farmer markets in nearby towns. The number of rural household plots is approximately 4.01 million.

Household plots are basic farms operated by individual households that carry out agricultural production for own consumption as well as for the market. The share of crop and livestock production by rural household plots in the total production of agricultural products is shown on Figure 3.

According to the latest Statistic data in Ukraine (2016) rural household plots had a significant share in production (Fig. 4.) of labour-intensive agricultural products, including: potatoes - 98\% (21 282.1 thousand tonnes), vegetables $-86 \%$ (8091.6 thousand tonnes), fruit and berries $-82 \%$ (1636.8 thousand tons), and milk $-74 \%$ ( 7675.9 thousand tonnes). Women play a significant role in the agricultural labour force and in agricultural activities. However, due to its subsistent nature and a lack of other income sources, household pig production remains strong in rural areas, but is characterized by low levels of breeding material, management and knowledge. 


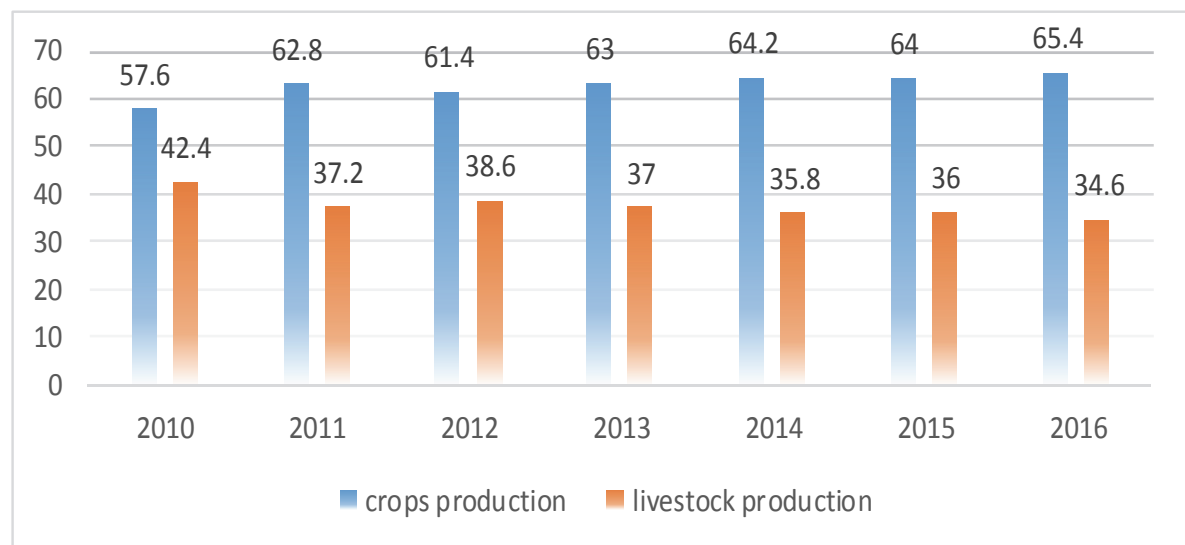

Fig. 3. The share of crop and livestock production by rural household plots in the total production of agricultural products, $\%$.

Source: data of the State Statistics Service of Ukraine, authors' calculations.

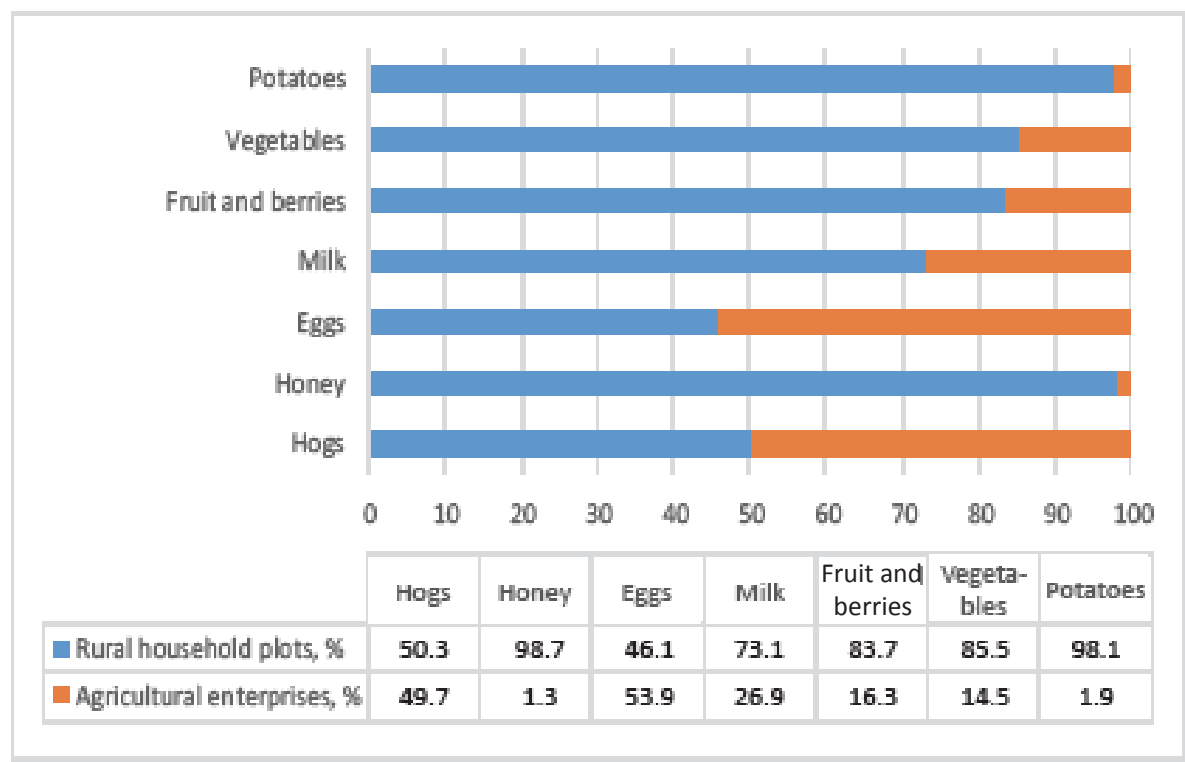

Fig. 4. The share of some crop and livestock products which were produced by rural household in $2017, \%$.

Source: data of the State Statistics Service of Ukraine, authors' calculations.

Agricultural cooperatives play a significant role in supporting small agricultural producers and marginalized groups such as young people and women. They empower their members economically and socially and create sustainable rural employment through business models that are resilient to economic and environmental shocks. Cooperatives offer small agricultural producers opportunities and a wide range of services, including improved access to markets, natural resources, 
information, communications, technologies, credit, training and warehouses. They also facilitate smallholder producers' participation in decision-making at all levels, support them in securing land-use rights, and negotiate better terms for engagement in contract farming and lower prices for agricultural inputs such as seeds, fertilizer and equipment.

Through this support, smallholder producers can secure their livelihoods and play a greater role in meeting the growing demand for food on local, national and international markets, thus contributing to poverty alleviation, food security and the eradication of hunger. According to the Euro Coop Annual Report, the cooperatives account for $89 \%$ of the agricultural market in the Netherlands, $79 \%-$ in Finland, 55\% - in Italy (total number is 39600 ), 50\% - in France (total amount is 22517 cooperatives). Next in turn, are the woodworking cooperatives, banking conglomerates, cooperative retail associations, etc. According to our calculations, the restoration of the state support for the development of the agriculture coops from 2018 will allow them to significantly increase their number, which by 2025 could reach almost 5000 units.

Agricultural cooperatives facilitate smallholder producers' access to:

- natural resources such as land and water,

- communication and knowledge of the markets,

- food and productive assets e.g. seeds, tools policy and decision-making.

The examination of the dynamics of the cooperative movement in the agricultural sector of Ukraine (Euro Coop Annual Report 2016, 2017) has proved that it is quite dependent on the level of state support for excellence and legal support to these processes. Among the major developments in agricultural cooperatives determining over the last decade were: steady reduction in the number of producers' cooperatives; preconditions for the emergence of network deployment service cooperatives; improving the regulatory role of the state in dealing with conflicts at the time of "contact" cooperation interests with the interests of big business. However, under discussion still remains the question of the role of the state in relation to the further development of production cooperatives and search trends improved monitoring of processes of cooperation at different levels of management, and will be the subject of our further research.

The need to introduce European quality standards in the process of Ukraine's integration to the EU also creates additional incentives for the development of Coops with the participation of rural households, especially in the field of milk and fruit and vegetable production. In terms that the existing operating conditions were maintained (lack of state support or intensification of credit support), the main trend of cooperative movement development was predicted by the method of analytical alignment of the dynamics series. 


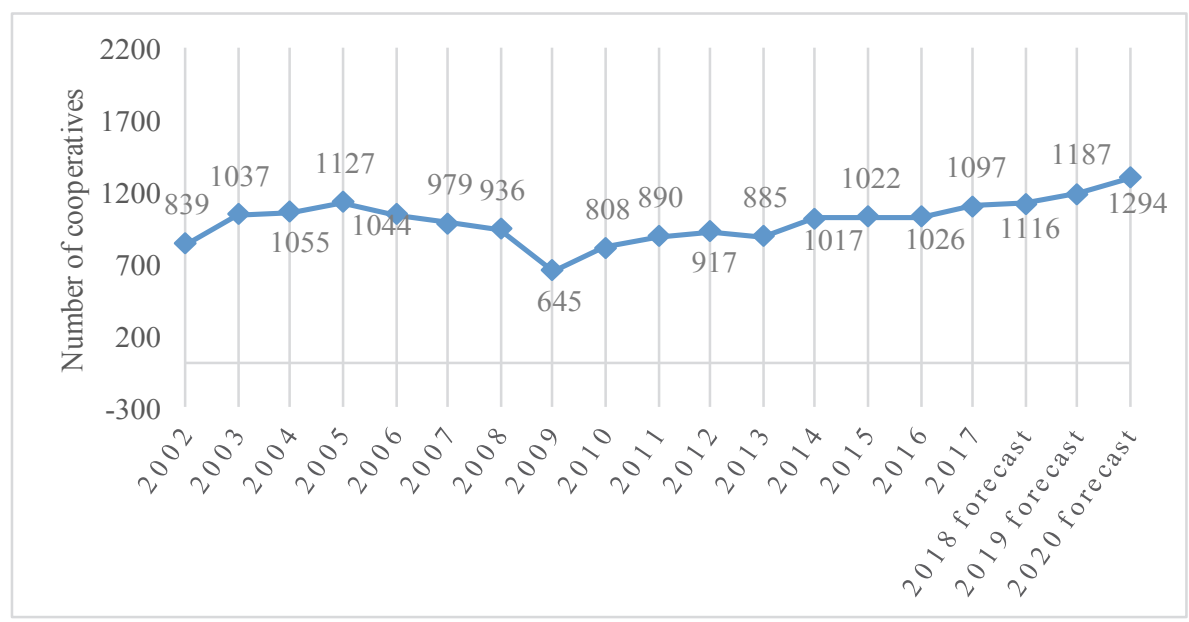

Fig. 5. Development trends of agricultural cooperatives in Ukraine.

Source: Statistical Yearbook of Ukraine for 2016, author' calculations.

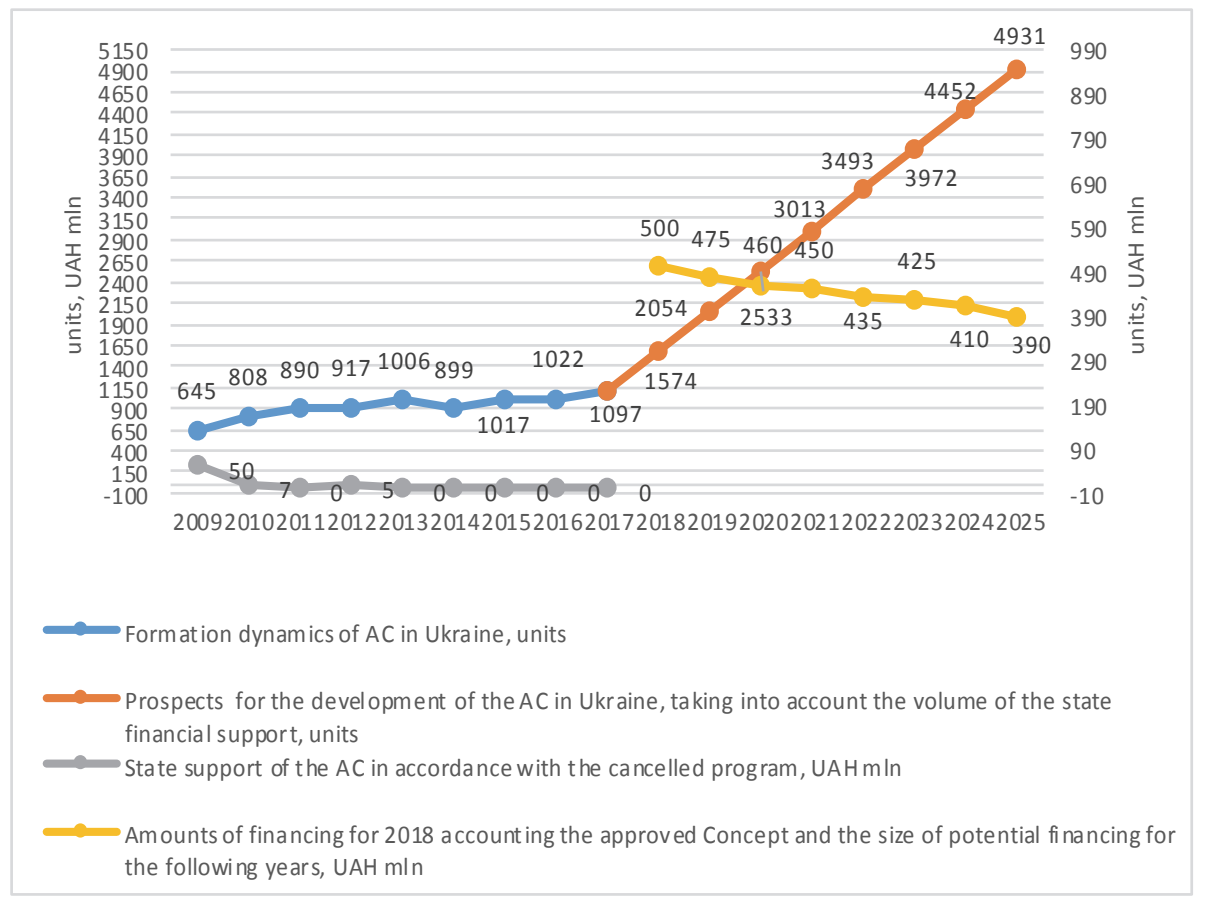

Fig. 6. Development dynamics of agricultural cooperatives at the appropriate level of state financing for the period up to 2025.

Source: calculated using data from the State Statistics Service of Ukraine and materials of the Concept of Development of Farmers and Agricultural Cooperatives for 2018-2020. 
However, the existing political prerequisites for the resumption of state support for the development of Coops from 2018 will significantly increase their number, which can reach nearly 5,000 units by 2025, provided funding is at the 2018 level (Fig. 6.). This takes into account the average number of members and the amount of funding for the creation of one Coop, which, depending on the direction of specialization, is estimated at 30-150 members and 200 thousand-2.5 million UAH, respectively. Based on the calculations, it is projected that annual increase in the amount of Coops within 450 units is projected. Given the current trends, the most active is the development of dairy and fruit and vegetable cooperatives.

Analysing such a slow dynamics and the background of cooperative development, the following factors which inhibit the evolution of Cooperative movement in Ukraine are observed:

- monopolization and oligarchization of markets and industries (top 70 agricultural companies in Ukraine operate approximately 6 million ha or roughly $20 \%$ of arable land, that cause price competition for the agricultural product for the benefit of agroholdings that are able to compete through large volumes of agroproduction and automation, robotization of production);

- rural poverty, inaccessibility of resources for cooperatives (unemployment and/or informal employment among the rural population reaches more than $40 \%$, while in cities this figure reaches $20 \%$, in addition the average wage in rural areas by $35 \%$ is less than the corresponding job in cities, moreover it is important when forming opportunities to start a cooperative, there is also bank lending, which is quite expensive for private households - about $30 \%$ a year);

- the weak ability of the rural population to reconcile the interests of the joint activity (the mental readiness of the population to cooperate is very low, given the experience and inheritage of Soviet collective farms, on the one hand, and the lack of positive collective cooperation experience on the other);

- the weakness of social capital in the countryside (above all, the low level of social capital is due to the almost lack of social infrastructure in rural areas);

- aging and absence of initiative among the rural population, lack of leaders (as the unemployment rate in the countryside is very high, young people move to cities or abroad in job search, mostly the most active ones);

- failure by the authorities to the already declared commitments.

In our opinion, for the successful functioning and development of agricultural co-operation in Ukraine it is necessary:

- to improve the legal framework that regulate the activities of agricultural cooperatives; to adopt the state program for the development of agricultural cooperatives (until 2025);

- to develop regional (local) programs for the development of agricultural cooperatives with financial support and taking into account the specifics of the region;

- to create financial and credit structures (including co-operative banks, development of rural credit unions), as well as conditions for investment activity in this sector with the system of state support; 
- to develop advisory and extension system in agricultural cooperation, to form a national coordination co-operative centre, systematically to cover scientific and practical issues concerning cooperation in the media;

- to provide support to the agrarian science in research, monitoring, studying the development of agricultural co-operation, and in organizing support for the creation of agricultural cooperatives;

- to improve the material and technical base of agricultural cooperatives.

An important area of rural economy and for the development of small farms and household plots is the use of organic farming that can adapt agricultural production to climate change and positively influence the socioeconomic development of rural areas.

About 44 million hectares of land are used for organic production in the world (3 times growth from 1999), or about $1 \%$ of the total area of farmland in the world. In the European Union, the area of land occupied by organic production is 11.1 million hectares.

Today's consumer demand for organic products is concentrated mainly in economically developed countries, because such products are more expensive than usual.

According to estimations (FiBL \& IFOAM - Organics International, 2017), on average, every resident of the planet spends on organic products about 8 euros per year. At the same time, most people spend on organic products in Switzerland 221 euros per year (2015) and 274 euros per year (2016), Luxembourg - 164 euros, Denmark - 162 euros.

The world market of organic production and consumption shows only positive dynamics, so the number of organic farmers has increased and for 2016 was $2.7 \mathrm{mln}$, which is $12.8 \%$ more in comparison with 2015 , significant is that on this market are emerging new countries and the total number of them shows the increase by $15 \%$.

According to estimates by the FAO (2018), the demand for organic production in the world will grow as the country's economy grows, education and income grow.

Ukraine has a unique opportunity to take one of the leading places among producers of organic products due to its natural, climatic and soil potential (Maslak, 2017). It should be noted that in the last one and a half decades, organic production in our country was actively developing.

In 2016, there were certified 210 organic farms in Ukraine, the average size of which was about 2 thousand hectares.

In recent years, domestic processing of organic raw materials and the production of cereals, flour, dairy and meat products, juices, syrups, jam, honey, oils, herbs have been established. The development indicators of the organic market in Ukraine is shown in Figure 7.

The growing solvent demand and the average consumption of organic agricultural products by the population of the European Union and other developed economies form certain opportunities for the use of growing production of organic products in Ukraine. In addition, based on the climatic and resource characteristics of Ukraine, preconditions are created to fill such agricultural niches as berries and nuts. 
Due to the lack of organic berry growing areas in the EU countries, their import from Ukraine is very promising. The volume of external supply of berries from Ukraine in 2017 grew by $66 \%$ - to 27 thousand tonnes, as compared to the previous year (16 thousand tonnes), while almost all deliveries were made to the EU.

Thus, for small agricultural enterprises and households in Ukraine it is possible and desirable to introduce and develop the production of organic berries which can reach $200 \%$ of profitability and nuts, the profit from which may be even greater.

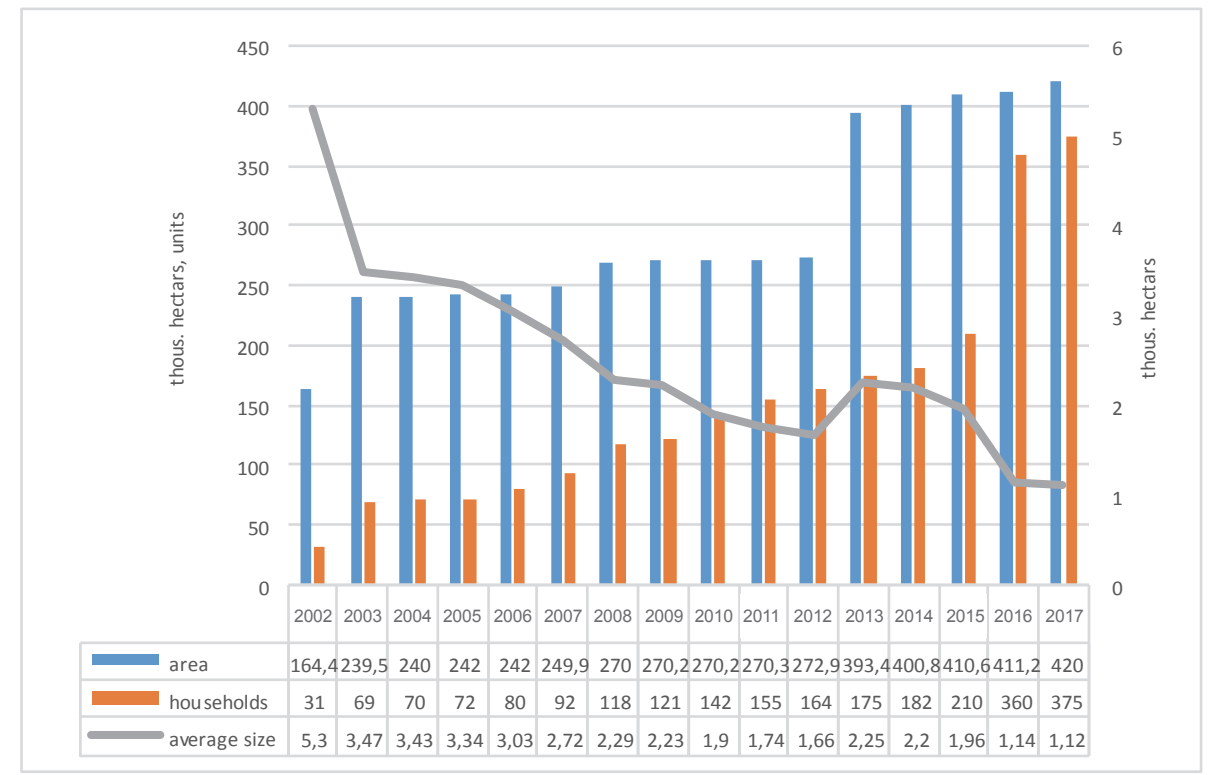

Fig. 7. Dynamics of the development indicators of the organic market in Ukraine.

Source: data from the State Statistics Service of Ukraine and the Ministry of Agrarian Policy and Food of Ukraine.

\section{Summary and conclusions}

The results of the study show that increasing the capacity of the small-scale farm sector is possible through the integration of small agro-producers into agricultural cooperatives. However, various economic, legal and institutional challenges hinder development of these processes in Ukraine.

Measures that will promote the development of rural households and small farms, which will increase their competitiveness:

- The specialization of production on labour-intensive farms, in which great interest is in active and creative work, and the size of production is not important (vegetable growing, potato growing, fruit production, beekeeping, livestock production, organic farming, etc.).

- The development of agricultural cooperatives. Its efficiency is proven by the long experience of many countries with a developed market economy. 
- The development of rural household plots and small farms requires more significant state support in the direction of encouraging the cooperatives' development, the organization of wholesale markets, the creation of advisory services, the organization of professional training for small businesses owners, information and analytical support.

- Introduction and (or) expansion of organic agricultural production, which is a guarantee of economic development on the European principles of sustainable development, due to: a) the production of highly profitable products, the solvent demand for which grows in the countries of the European Union and the world; b) thus ensuring environmentalization of agriculture and the economy as a whole of Ukraine. 


\section{References}

Balmann, A. (2014). Does Ukraine need agroholdings? Efficiency and profitability issues. $5^{\text {th }}$ International Large Farm Management Conference, Kyiv September, 18. Retrieved from: https://doi.org/10.13140/2.1.2548.8640 (access date: 10.11.2018).

Dankevych, Y., Dankevych, V., Chaikin, O. (2016). Ecologically certified agricultural production management system development. Agricultural and Resource Economics: International Scientific EJournal, Vol. 2, No. 4, pp. 5-16. Retrieved from: www.arejournal.com (access date: 11.10 .2018$)$.

Demyanenko, S. (2008). Agriholdings in Ukraine: Good or Bad?. Retrieved from: http://www. apd-ukraine.de/images/AgPP_21_Eng.pdf (access date: 10.02.2019).

Euro Coop Annual Report 2016 (2017). Retrieved from: http:/www.eurocoop.coop/uploads/Euro\%20 Coop\%20Annual\%20Report\%202016\%20(No\%20Accounts).pdf (access date: 10.02.2019).

FiBL \& IFOAM - Organics International (2018). The World of Organic Agriculture. Retrieved from: https: //www.organic-world.net/yearbook/yearbook-2018/pdf.html (access date: 10.11.2018).

Ivchenko, V. (2007). Formation and development of the national innovation system of Ukraine as a prerequisite for building a competitive state economy. Strategy of development of Ukraine. No. $1 / 2$.

Karasova, N. (2014). Organic production as an innovative trend in export-oriented development of Ukraine's agriculture. Management Theory and Studies for Rural Business and Infrastructure Development, Vol. 36, No. 2, pp. 308-315. Retrieved from: http://dx.doi. org/10.15544/mts.2014.027 (access date: 10.02.2019).

Key indicators on organic agriculture worldwide (2017). Fibl Statistics. Retrieved from: https:// statistics.fibl.org/world/key-indicators-world.html (access date: 10.11.2018).

Lupenko, Yu., Khodakivska, O.V., Shpichak, O.M., Yurchenko, IV, Matvienko, A.P. et al. (2018). Results of the survey on agricultural land use patterns in Ukraine. K.: NSC IAE.

Lupenko, Yu., Mesel-Veselyak, O., Spikulyak et al. (2018). Development of management forms in agriculture: problems and solutions: Scientific report. National Research Center "Institute of Agrarian Economics". K .: NSC IAE.

Maslak, A. (2017). The status and prospects of the organic agricultural products market in Ukraine. Baltic Journal of Economic Studies, Vol. 3, No. 2, pp. 81-85.

On the private rural households (2003). The Law of Ukraine. Information from the Verkhovna Rada of Ukraine (VR). No. 29, p. 232.

On Urgent Measures to Accelerate Land Reform in the Field of Agricultural Production (1994). Decree of the President of Ukraine.

State Statistics Service of Ukraine (2017). Retrieved from: http://www.ukrstat.gov.ua (access date: 10.02.2019).

Terziev, V (2016). Entrepreneurship in organic production - an incentive for sustainable rural development. Agricultural and Resource Economics: International Scientific E-Journal, Vol. 2, No. 4, pp. 30-42.

The National Investment Council of Ukraine (2018). New report agricultural sector Ukraine securing global food supply. Retrieved from: https:/www.agroberichtenbuitenland.nl/actueel/ nieuws/2018/07/04/ua-report-investment-council-ua-agriculture (access date: 10.02.2019).

The official site of Ministry of Agrarian Policy and Food of Ukraine (2017). Strategy for Agrarian Sector Development "3+5". Retrieved from: http://minagro.gov.ua/node/21439 (access date: 10.11.2018).

The official site of Ministry of Agrarian Policy and Food of Ukraine (2017). Integrated Strategy for the Development of Agriculture and Rural Areas in Ukraine for 2015-2020. Retrieved from: http://minagro.gov.ua/node/16025 (access date: 10.11.2018). 


\title{
PERSPEKTYWY I WYZWANIA DLA ROZWOJU MAŁYCH FORM PRZEDSIĘBIORCZOŚCI W ROLNICTWIE UKRAINY
}

\begin{abstract}
Abstrakt
Artykut podsumowuje praktyke tworzenia $i$ funkcjonowania matych form przedsiębiorczości $w$ rolnictwie Ukrainy, ocenia ich rolę i zdolności na obecnym etapie oraz w przyszłości, określa priorytetowe, pożadane kierunki dalszego rozwoju społeczeństwa, a także mechanizmy ich zapewnienia. Konieczność wdrożenia spójnej polityki rozwoju działalności gospodarczej na obszarach wiejskich jest udowodniona przede wszystkim przez rolnictwo rodzinne, które jest $w$ stanie zapewnić maksymalna stopę zatrudnienia ludności wiejskiej. Ze względu na wyżej wymienione procesy agroholdingi zmniejszyly zdolność ludności wiejskiej do prowadzenia działalności rolniczej.

Udowodniono również, że w celu zwiększenia skuteczności produkcji rolnej, rentowności wiejskich gospodarstw domowych wynikajacej z produkcji i sprzedaży produktów rolnych, zatrudnienia ludności wiejskiej oraz rozwoju infrastruktury rynku rolnego, konieczne jest zintensyfikowanie tworzenia spółdzielni rolniczych, zwłaszcza w sektorach, w których przeważa produkcja matych form przedsiębiorczości. Stwierdzono, że niezwykle ważne jest, aby wprowadzić stały stan wsparcia finansowego i innego wsparcia na rzecz rozwoju spółdzielni rolniczych i matych form rolnictwa na obszarach wiejskich, koncentrujac się na wspieraniu tych ostatnich poprzez spółdzielnie, w których uczestniczą.
\end{abstract}

Słowa kluczowe: agroholdingi, gospodarstwa domowe, zatrudnienie na obszarach wiejskich, spółdzielnie rolnicze, rolnictwo ekologiczne, Ukraina.

Accepted for print: 13.03.2020.

Unless stated otherwise all the materials on the website are available under the Creative Commons Attribution 4.0 International license.

Some rights reserved to the Institute of Agricultural and Food Economics - National Research Institute.

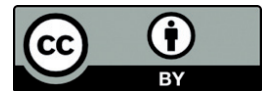

